\title{
NON-PLACES AND THE LAW: A PRELIMINARY INVESTIGATION
}

\begin{abstract}
In the context of the significant literature on Marc Augé's concept of non-places, including its various applications in different disciplines, and also constantly growing legal geographical analyses, it is striking that, to date, there have been no more focused discussion on non-places and the law. This paper aims to begin filling this noticeable gap. It focuses on an original presentation of Augé's concept and distinguishes three levels of non-places: their objective, material level (e.g. the buildings of non-places); the intersubjective, social level (the specific, distinctive feel of non-places, such as anonymity and detachment); and the purely individual, subjective level (the way particular people assess a specific non-place). The paper not only argues that Augé is already sensitive to the law in his original account of non-places, but also that the law - while directly irrelevant for the subjective level - is nevertheless very important for the objective and intersubjective levels of non-places, as, ultimately, it is a co-constituting factor of these aspects of the discussed type of sites.
\end{abstract}

Keywords: spatial turn, legal geography, Marc Augé, non-places, law.

\section{NIE-MIEJSCA I PRAWO: WSTĘPNE ROZWAŻANIA}

Streszczenie. W kontekście obszernej literatury na temat koncepcji nie-miejsc Marca Augé, włącznie z jej wieloma aplikacjami w różnych dziedzinach, a także stale rozwijanych geograficzno-prawnych analiz, zaskakujące jest, że dotąd nie przeprowadzono bardziej skupionej dyskusji nad nie-miejscami i prawem. Celem tego artykułu jest rozpoczęcie wypełniania tej luki. Skupia się on na oryginalnym ujęciu koncepcji Augé i wyróżnia trzy poziomy nie-miejsc: ich obiektywny, materialny poziom (np. budynki nie-miejsc); intersubiektywny, społeczny poziom (specyficzna, wyróżniająca atmosfera nie-miejsc, taka jak panująca w nich anonimowość i poczucie zdystansowania), oraz wyłącznie indywidualny, subiektywny poziom (to, jak poszczególni ludzie oceniają konkretne nie-miejsce). W artykule przekonuje się nie tylko do tego, że Augé jest uwrażliwiony na prawo już w jego pierwotnym ujęciu nie-miejsc. Ponadto prawo - jakkolwiek bezpośrednio nieistotne dla subiektywnego poziomu - jest bardzo ważne dla poziomów obiektywnego i intersubiektywnego nie-miejsc, jako, ostatecznie, czynnik współkonstytuujący te aspekty komentowanego rodzaju miejsc.

Slowa kluczowe: zwrot przestrzenny, geografia prawna, Marc Augé, nie-miejsca, prawo.

* Jagiellonian University in Krakow, Poland, Faculty of Law and Administration, Department of Sociology of Law, michal.dudek@uj.edu.pl

A previous version of this paper was presented at the International Congress "Global-Regional-Local. Institutions, Relations, Networks. Past and Future of the Sociology of Law", May 21-23, 2014, in Oñati, Basque Country, Spain. 


\section{INTRODUCTION}

The general aim of this short study is to present a preliminary look at and discussion of Marc Augé's concept of non-places, based on its fullest account, which was originally expressed in 1992 in Non-lieux, introduction à une anthropologie de la surmodernité [Non-Places: An Introduction to Supermodernity] (Augé 2008 - second edition of English translation), from the broadly understood socio-spatio-legal perspective. Specifically, hereinafter one argues that not only was this particular perspective previously absent in the nonetheless quite significant and still growing scholarship on non-places, but also that Augé's original account of non-places seems already to be informed by a very basic kind of sensitivity to legal context. Further elaboration of this sensitivity allows for the proposal of a new way of explaining this quite often misunderstood concept and helps us to grasp it, which is no easy task, given the complexity of Augé's narrative. At the same time, a general account of the law's important and, to a certain extent, even constitutive role for non-places is presented and explained. Such an attempt to show a neglected legal dimension of Augé's influential concept proves that it can still be thought-provoking and that there are aspects of it which have yet to be thoroughly discussed, almost 30 years after the original French publication of Augé's essay.

However, in the face of the impressive development of legal geography, and especially considering its relatively recent highly original theoretical frameworks (e.g. Delaney 2010; Philippopoulos-Mihalopoulos 2015), one must admit that the proposed introductory conceptualization of the intersection of non-places and the law is only one of many possible approaches. In no way do ideas below rule out any other accounts of the title relationship that can be created within various legal-geographical frameworks; rather, the paper encourages such an enterprise. In the end, this study should be thought of as an invitation to begin considering the non-places-law nexus. Both elements of this relationship are extremely complex, thus it would be naive to assume that a short, even basic study can cover all of the subtle details of the issue. However, the first step in showing and understanding how non-places and the law relate to one another must be taken.

\section{THE BASICS AND NON-BASICS OF NON-PLACES}

Even though the concept of non-places was already proposed and used before Augé did so (e.g. Augé 2008, 69), it is he who popularized the concept and gave it the meaning most-known today and more or less faithfully employed by a wide range of scholars representing various disciplines. The basic, most general thesis of Augé $(2008,28)$ is that, today, one experiences a proliferation of non-places 
that are opposed to the category of anthropological/sociological places. The latter are defined by the particular culture localized in a given time and space and by the specific functions they fulfill with regard to individuals (Augé 2008, 42-43). Namely, places are a source of meaning and have significance for those who inhabit them. They have a historical, sometimes even highly intimate, character for those who identify themselves through these sites and their relationship to them. By contrast, non-places lack features of identification, relationality, and historicity (Augé 2008, 63-64). Not only are they understood negatively regarding anthropological places, they also fulfill a completely different set of functions. To name just few of the most typical examples, non-places make fast movements/ transitions possible (e.g. highways, airports), but are also suitable for temporary stays (e.g. global chain hotels/motels, but also refugee camps) and consumption (e.g. shopping malls, global chain supermarkets) (Augé 2008, 28).

Even though one might get the impression that places and non-places are fixed, objective categories, in the end, they can and should be understood as idealizations - two extreme points on one axis that do not exist in reality in a pure form (Augé 2008, 64). Namely, Augé $(2008$, 44) himself complicates this distinction when he explains the concept of historicity, a feature of places, not non-places. According to him, a place fulfills its condition of historicity if it is outside the scope of history understood as a science. Next, Augé (2008, 45-46) stresses that an anthropological place is basically subjective; it is an individual's image of his or her relationship with a certain site. As one might easily guess, due to "the two sides of the same coin" character of the places/non-places distinction, the same can be said of non-places. However, the experiencing of these sites is not constituted through the sense of identity, relationship, and history (outside history textbooks), but through a sense of detachment, solitude, anonymity, similarity, or even sameness and specific deindividualization (Augé 2008, 83). Individuals in non-places consider themselves as only one of many nearly identical people. One can say that, to consider a certain site as a non-place with regard to a given individual, the person has to have the impression that in this site, she or he is not a "one and only," but just "one of the many" of the same kind.

In his later writing, Augé does not commit the same specific mistake (see Introduction to the Second Edition, Augé 2008, VIII), but in light of his original essay, one might actually get the impression that, in non-places, there are only visitors. Significantly, Augé seems to neglect the obvious fact that, besides visitors or users (e.g. travelers or customers) in non-places, there are also inhabitants of these sites (broadly understood, but internally very diverse staff members or service providers) whose behaviors toward visitors are a significant medium for the experiencing of the non-place among the latter. For an "insider," something so standardized, schematized, and fitting regarding the general account of the non-place, such as an enormous international airport, can still be regarded as an anthropological place. In the end, the airport staff, or those who work for global 
chain hotels, are much more familiar with these specific environments. Their relationships with these sites are also markedly different than those experienced by "outsiders," who simply use or pass through them, but do not "dwell" in them. Thus, quite understandably, one can safely say that a given site can be regarded at once by some as place and by others as a non-place.

This general remark fits perfectly well with the subjective character of place/ non-place distinction that Augé stresses in many parts of his essay. Nevertheless, it would be a mistake to emphasize only the subjective character of places and non-places, giving the impression that they are one-dimensional and that their specific ontologies can be reduced to just the individual's experience. In the end, individuals' approaches constituting a place or non-place always refer to something objective, "extra-experiential," to some actual physical, architectural creation and setting. Accordingly, one can speak of the dual character of places and non-places. They are material, externally observable creations and kinds of relationships given individuals have with them. In other words, they are objective, physical formations and their subjective experiences. As mentioned above, non-places are defined by the very specific senses of anonymity, solitude, and deindividualization felt by particular individuals regarding these sites.

However, when one looks at the list of experiences that define non-places according to Augé, one might start to wonder: do notions of similarity, detachment, or the other characteristics mentioned above actually refer purely to individual, subjective evaluations, or are they, in fact, more objective - or to be more precise, intersubjective - characterizations of social relationships in sites described as nonplaces? To put it differently, is the sense of being just one of many of the same kind, and not the one and only really an only individual experience, or is it more general social regularity, a characteristic of a large part of social interactions in non-places that affects many individuals in a similar way, but who can, in the end, assess it differently? Namely, for one person, the anonymity, solitude, and specific traveler's sense of self-centeredness, which are in a way inherent in large modern international airports, can be very soothing, while for another person they can be simply unnerving.

This conclusion can even allow us to say that, in fact, non-places have triple character, a quite complex ontology. They can be described as being based in objective, actual physical creations and settings where many intersubjective, social relationships can be characterized by similarity, mutual anonymity, or sometimes even disinterest. These, in turn, can be and are differently evaluated from totally subjective, individual perspectives of some of the people in these sites (this triple model is inspired by the distinction of material, social, and mental spaces used by Blank and Rosen-Zvi 2010). Following this suggestion of non-places' triple character can be useful in the elaboration of the relationship between non-places and the law. However, before proceeding to this main task, a few more general remarks are warranted. 


\section{CONTEXT AND AIM OF THE STUDY}

Even though, or maybe just because, Augé's account of non-places can be regarded as quite vague and open to different interpretations, and thus full of controversy, this concept made a tremendous career. It is commented on and discussed, usually outside any particular context, in a more general, conceptual manner as a research topic in itself (e.g. Bosteels 2003; Merriman 2009). It is also compared with other more or less well-known spatial concepts in the social sciences and humanities, such as Michel Foucault's heterotopia (e.g. Czaja 2013) or Edward Relph's placelessness (e.g. Freestone and Liu 2016) and used in more specific research areas, such as globalization (e.g. Ritzer 2007), literary and film studies (e.g. Gebauer et al. 2015), or design (e.g. Coyne and Stewart 2007). This is still a far from exhaustive enumeration, because Augé's non-places even inform some diverse empirical research and are used in a wide array of case studies in different disciplines and subdisciplines (e.g. Fitzgerald and Robertson 2006; TawilSouri 2011; Costas 2013).

This proves, quite undeniably, that non-places are a truly thought-provoking concept of impressive "bearing capacity." In the end, Augé's notion is employed in very different contexts. However, sometimes one might get the quite justified impression that some authors do not use it faithfully, but instead simply amend this general concept to serve their own research goals, which seems to be caused by the intricacy of Augés argumentation style. Whether similar amendments to the concept of non-places are made in the case of the present study is, naturally, open to discussion.

Nevertheless, in the face of the staggering number of comments and applications of the non-places concept, what is most striking is the absence of its analysis from the broadly understood legal perspective. Representatives of the legal sciences seem to be completely oblivious to Augé's most famous work. Moreover and more specifically, dynamically developing analyses of the spatial dimension of the law and legal phenomena (i.e. legal geography or law and geography studies, which can be regarded as a part of a wider spatial turn in social sciences and humanities) also do not seriously take into account this influential concept. Even when non-places are actually referred to, they are still treated very perfunctorily (e.g. English 2003, 470; Cohen 2008, 193-194; Anders 2009, 137; Whitecross 2009, 58; Young 2014, 130; Maniscalco 2015, 198, 208, 221; Barr 2016, 18, 187; Dahlberg 2016, 22). Naturally, one might say in response to this that there is nothing interesting about non-places, from a legal perspective. Perhaps not much is said about non-places and the law because there is simply nothing to say about it.

Although this or other similar approaches are possible to take, they are flawed and misguided. Namely, sites popularly described as examples of non-places 
(for instance, airports or refugee camps) seem to be interesting areas of specific socio-legal phenomena, such as micro-jurisdictional differences in comparison to a state's jurisdiction - as, in the end, non-places can be regarded as sites under a nation-state's jurisdiction that have their own legal peculiarities unknown to other distinguishable sites in the given state - but also, or even more importantly, the law appears to be specifically constitutive for them. This is exactly the aim of the presented study: to reveal and try to explain one particular approach to the legal dimension of or the law's importance for non-places. This feature of the "legality" of the non-places concept - hitherto neglected in various discussions on it - is even something Augé suggests between the lines, though he and other scholars (including sociologists of law and legal geographers) never elaborate on it. The elaboration of this feature begins with general remarks about non-places and the law - references to some of the "law's traces" found in Augé's original essay.

\section{NON-PLACES AND THE LAW - GENERAL REMARKS}

When one thinks about the intersection of non-places and the law, one might first look at the original French notion of non-lieu. Not only does this word mean "non-place," it also, and even more commonly, is the legal notion of the dismissal of a case, often because of a lack of grounds for prosecution (Augé 2008, 82, footnote 6).

Next to this additional and purely legal meaning of the original, French notion of non-lieu, one can easily find in Augé's account other, even more convincing arguments that justify the enterprise proposed in this paper: an effort trying to map the relevance of the law for non-places. Namely, Augé $(2008,43)$ explicitly states that broadly understood spatial structures correspond to some sort of rules. To put it differently, physical sites for human activity are co-constituted (with other factors) by social norms, regardless of whether these norms are customary, moral, religious, or legal. Spaces people inhabit or merely pass through have specific identities and can be distinguished from one another, not only because of their objective, visible, physical features, but also because of the fact that, for instance, in one type of space some activity can be even explicitly proscribed, whereas in another type the same activity can be normatively irrelevant (also, this can occur within one national legal jurisdiction). Needless to say, such an idea seems to be one of the fundamental assumptions for legal geography. As a consequence, nonplaces should also have some specific rules that co-constitute them and how they are experienced. Luckily, one does not have to guess about them, because Augé is remarkably clear when it comes to the issue in question.

Augé $(2008,77-78)$ argues that non-places, such as highways, global chain shopping malls or supermarkets, motels and hotels, and airports, define themselves and function through normative messages. Non-places are co-constituted through rather clear, non-ambiguous, and often strict rules (for example, interfering in 
one's privacy) for functioning in them. These rules - expressed textually or visually - are addressed particularly to those who visit or pass through them.

What can and should be added to the very basic normative, rule-centered characteristics of non-places in Augé's original account is a stressing of the following. The mentioned normative messages either resemble legal rules or simply are legal rules created by legislative bodies explicitly for the sake of sites that can be characterized as non-places. To acknowledge this, consider the legal regulations concerning traveling on highways in a given country; the complex web of rules of conduct in an international airport, where international aviation associations and national and often internal (specific to a given airport) regulations intertwine; or the plethora of written, but also strictly visual, instructions for hotel guests.

Moreover, this particular remark requires us to refer once again to the issue of micro jurisdictions, suggested earlier, and to consider the following. There are general laws over the state territory in which a given non-place is physically located, and this non-place has its own characteristic legal rules or rules with some legitimizing foundation in official law that do not function outside the non-place in question. In other words, one can say that non-places often require from their users or passersby things that are not expected of them in any manner, not only - in Augéan terms - in more intimate, personal anthropological places, but also in sites that are usually conceptualized as instances of public places. In the sites of these last two types, there are also some rules that are relevant for them, yet often they are non-legal or, even if they are legal written rules, they are still not so specific, detailed, and miniscule as those in non-places.

The above is only a preliminary discussion, yet it shows that there is some legal relevance to non-places. Briefly, the French explicitly legal understanding of the notion of non-lieu and Augé's clear and unambiguous comments on the general spatiality-rules nexus, coupled with some basic characteristics of non-places' specific normative messages, that can be further described as generally legal or legal-like and not functioning outside the given non-places. Often, these are more detailed and even more demanding than the rules co-constituting other types of sites. However, there is more to say about non-places and the law than simply these general remarks. Namely, one can propose discussing the law's relevance for nonplaces in a more ordered, organized way, yet still retain a considerably high degree of generality, with the use of the already-suggested triple understanding of non-places.

\section{NON-PLACES AND THE LAW - SPECIFIC REMARKS}

Even though Augé proposes understanding non-places in terms of actual, material, physical sites, in addition to the individual, subjective relations particular persons can have with these sites (seen most explicitly in Augé 1999, 106, 109), one can argue that he should also clearly take into account a specific intermediary 
between the objective and subjective levels of non-places. Namely, non-places are not only distinctive in comparison to other kinds of sites for human activity, because of their physical forms and appearances and the ways people relate to them, but also because interpersonal, intersubjective relations, those interactions people most usually engage in in non-places, are very specific. In other words, non-places are not only highly visually and architectonically standardized and leading their visitors to particular feelings or emotions (or a lack of them). They are also marked by some specific social, interactional features - not purely individual subjective experiences of these sites, but their traits, beyond the mere physicality, that can similarly affect whole masses of people who use or pass through non-places.

In consequence, one can analytically distinguish three levels of nonplaces. First, the objective level is about non-places as concrete material, architectural objects, buildings' exteriors and interiors in all their complexity and multifacetedness. Second, the intersubjective level concerns relatively common features of social relations that most typically happen in non-places and thus influence a plethora of individuals using or passing through these sites in a very similar way - many see or encounter the same things and situations in non-places. Third, the subjective level refers to purely individual, personal evaluations or experiences of non-places by a given person, ones that can even be quite surprising, in light of the specific non-place's objective and intersubjective levels and how other people individually assess the particular site. For instance, a specific visitor can be very satisfied by a given non-place, such as its appearance and the predominant characteristics of the social relations that happen within it, whereas other visitors who encounter the same things and situations assess them completely differently. This basic triple vision of the non-place, which can be interpreted from Augé's writings on non-places, is useful in discussion of nonplaces and the law, as called for in this paper. The subsequent subsections address the issue of how the broadly understood law relates to non-places or, to be more precise, to each of their analytically distinguished levels.

\subsection{Non-Places' Objective Level and the Law}

The law's relevance for the objective level of non-places is the easiest to address. In the end, one can simply say that the law, with its specific regulations concerning building construction, standards to be realized, or even building permits alone, actually plays a significant role for non-places in their most basic sense of specific constructions where different kinds of interactions happen and particular issues are taken care of by people. In short, the law regulates the physical creation of non-places and even, to a certain degree, their subsequent material maintenance. Without construction regulations and a wide array of legally determined standards and requirements that are periodically controlled, building 
permits and other kinds of public administration institutions' legal involvement, including public procurement procedures, it is hard to imagine the creation and existence of a non-place as a building or a broader material infrastructure.

Having said that, one should stress that the above does not mean that the law's influence on non-places' objective level is so all-encompassing that it determines the entirety of it. The law is, indeed, fundamental to non-places' physical existence, but through the law one simply cannot explain all of the multifaceted material details of these sites, such as those that can be seen (e.g. sizes and colors of fonts used in signs, or decorative elements like fountains or statues), touched (e.g. handrails), heard (e.g. intercom messages or Muzak), or even smelled by those present (e.g. air fresheners). In the end, such details, which in conjunction constitute the broadly understood exteriors and interiors of non-places, are ultimately determined by extra-legal factors, including architectural norms, design paradigms, fashions or trends popular at the moment, more general aesthetic tastes, financial capabilities, and the products and services actually offered by potential contractors who may be chosen to complete the construction of a given non-place. The broadly understood aesthetics and material functionality of nonplaces, including their non-human constituents that can be grasped by human senses, are not completely irrelevant to the law, but the law does not determine these aspects thoroughly, to the most miniscule detail. This leads to the following. Even at their most basic, objective level, non-places are too complex and detailed to be explained exhaustively with reference to the law, although the law is still, to a certain considerable extent, relevant for this particular level of them.

When speaking of experiencing non-places, one must stress that they are not hollow, lifeless objects, whose experiencing is similar to being alone in an empty room or building, when a person can observe all the material aspects of a given site, with no actual interpersonal interactions in it. On the contrary, for a non-place to actually be a non-place, its specific aesthetics or material functionality are not enough. Next to aesthetics and functionality, there must be some specific social relations, that is, interactions between people within the non-place that are merely instrumental to or are actually a realization of the main, intended functions of the given non-place, like a transition, a temporary stay, or consumption, as mentioned above. Additionally, a non-place's specificity, when it comes to the human relations that happen in it, can be grasped by the already-noted concepts of detachment, solitude, anonymity, similarity, and deindividualization. These are the features of non-places Augé refers to constantly, not to mention the countless commentaries and applications of his concept - they can be said to constitute the intersubjective level of non-places. They are the traits of the social environments of non-places that most of the people in these sites encounter and are affected by, even though they may assess them differently, referring to the idea of the subjective level. Before one can try to address this particular level of non-places in connection with the law, one must first comment on the second, intersubjective level. 


\subsection{Non-Places' Intersubjective Level and the Law}

As previously noted, the intersubjective level of non-places concerns the social, interactional conditions for those who are in non-places, especially those who use or pass through them, but are not these non-places' broadly understood staff (i.e. those who work in non-places). To be more precise, this level is about the distinctive feel, atmosphere, or climate in non-places of detachment, solitude, anonymity, sameness, and deindividualization. Those who use or pass through non-places, regardless of whether they are drivers on a highway, travelers in an airport or central railway station, motel or hotel guests, customers in a shopping gallery or a supermarket, or fun seekers in an entertainment park of a global franchise, are all within the range of this feel, but naturally each of them can assess that which they experience differently.

What constitutes this feel? The objective, material aspects of non-places also take part in its creation and maintenance; in the end, non-places are very often highly similar to each other, on the basis of their looks and material functionality alone, but one can say that a very particular atmosphere or climate in non-places comes from the sociality that is developed within them. In short, the ways people behave in non-places also create non-places. For instance, to achieve an environment where a specific solitude seems to be one of the predominant features, those who pass through it should simply behave in a highly self-centered way, focusing only on themselves and avoiding taking any interest in the others present.

However, non-places are non-places in their intersubjective, social, and interactional sense, not only because of what their visitors, users, or passersby "bring in" to them in terms of actual behaviors, but also, or even especially, because of what is already in non-places that visitors encounter soon after entering them. In other words, visitors' actions are important in non-places, but even more important are the actions of those who simply work in non-places and with whom visitors interact the most, because they have to engage the staff to realize the specific goals to which these non-places are ultimately dedicated. In the end, senses of detachment, sameness, or deindividualization - all defining features of a non-place - are achieved not only through the highly standardized aesthetics of the building or construction, such as a lack of visual or auditory highlighting an ethno-cultural specificity of the region or country where the given non-place is located or the ubiquitous presence of global brands, their advertisements, and products, but also through similarly standardized ways in which non-places' staff members behave with respect to visitors. Non-places can be regarded as sites for providing specific goods and services for clients who do not form a single, internally consistent (in socio-economic-demographic terms) group, but are actually extremely diverse. Nevertheless, those who work in non-places typically approach non-places' clients in a very standardized and unified way, because 
doing so is an element of what is professionally and even legally required of them: providing services of a particular quality, which is often specified in special, dedicated documents that are also of legal significance.

One can make such reference to the law not only in the course of explaining the behaviors of non-places' staff members with respect to their broadly understood visitors, but also when addressing the wide array of standards expected to be followed by visitors themselves. As suggested above, those who use or pass through non-places are subjected to a plethora of visual or textual normative messages of explicitly legal or legal-like provenance that often are far more detailed and stricter than rules found outside non-places. However, the law also seems to play a more general, fundamental role in non-places, or at least their intersubjective level, that one should factor out.

The legal or legal-like rules specific to non-places that are responsible for their micro-jurisdictional characteristics suggested earlier, regardless of whether they are manifest through the actions of staff members with respect to visitors or through the wide array of textual, visual, displayed, or announced instructions or requirements addressed directly to visitors, bring all the visitors to a state of sameness. In the end, there is one set of normatively determined actions or situations involving non-places' staff members, and an even easier to determine set of normative messages for the countless and significantly varied visitors. In consequence, if their specificity and individuality are not erased outright, they are certainly significantly neglected, leading to the creation of "average person" figures. These people are reduced to those traits deemed the most crucial for a particular non-place, such as the amount of money they spend or the weight of their luggage. People are thus deindividualized and detached.

This detachment is not only from the contexts from which people come and are most familiar with - these are temporarily replaced by standardized, "if you've seen one, you've seen them all" non-places. The detachment is also from others, because everyone is effectively occupied with their individual affairs and plans, filtered through the intricacies of the non-place - a site on which their affairs and plans ultimately depend. In effect, one can also speak of a peculiar mutual anonymization of people using or passing through non-places. Ultimately, everyone seems to everyone else to be similar to the blurry view outside the window of a moving vehicle. Such an interpretation is already justifiable in the face of two arguments Augé $(2008,80,81)$ makes. He argues that non-places create a mass of single, mutually anonymized and even alienated people whose specificity is obscured, leading to their deindividualization and specific sameness. Moreover, he raises the issue of normative messages, on the basis of which nonplaces function and characteristically influence those within their range. It is this second argument that drives the present paper.

In sum then, one can say that the sameness that is so distinctive for non-places is achieved through normative messages which upon even a brief examination 
can be regarded as legal or at least legal-like. One can add to that some further supplements to Augé's account, such as the issue of normative bases for actual behaviors of non-places' staff members, which are also crucial to the overall nonplace experience. Moreover, the influence of specific non-place's rules can be "felt" even before one actually, physically enters a non-place. To acknowledge this, just consider weighing a piece of luggage to comply with airlines' requirements before going to the airport.

Augé's presentation of non-places clearly and explicitly does not take into account subtleties like those mentioned above because of the very broad, general character of his analyses (in the end, Augé does not address particular kinds of non-places in detail) or their frequent exaggeration. For instance, he argues that non-places are creating a mass of individual, mutually detached people, but is this really always the case? In the end, one can easily imagine a scenario when a similar experience in a non-place is a starting point for creating a specific temporary community of those who have encountered the same issue and evaluated it similarly. More specifically, think of those passengers who have not been informed properly about new luggage standards and are thus made to throw away excessive or forbidden goods, or to pay additional fees to bring on board some of their belongings. Needless to say, such situations can bring different people together, thus demonstrating that non-places are not so devoid of some more communal, solidary thinking and actions, as Augé's argumentation may suggest. However, in light of this paper's aim, one should first of all stress that behind such situations there are still very specific legal or legal-like rules of non-places.

In most cases, when the latter function properly, they contribute to a distinctive feel of alienation from other people, which Augé describes. He, or those who wish to analyze non-places' legal dimension further, should more fully consider "the opposite of the same coin" situation: what are the consequences of some distortions in the functioning of non-place's characteristic rules? Augé $(2008,81)$ even suggests this direction when he makes a remark on the "individualizing power" of non-places (and not their default deindividualizing influence). However, the individualization of some previously nearly completely anonymous individuals can be regarded as initiated by their nonconformity with some of the rules functioning in non-places. In other words, in non-places, one is not oneself, but instead one of the many nearly identical people, as long as one follows the rules. Naturally, it is still possible to become oneself, for instance, a non-place's visitor or passerby starts being called by his or her name by non-place's staff members, but when one breaks some rule, or when something bad or unwanted happens. For a more specific example, consider airport intercom announcements calling a specific passenger who is late for boarding, or supermarket or shopping gallery announcements asking the owner of a car with a specific registration number to move it or to simply come to the security office. 
Situations like these can be seen as proof of the general, contractual (and thus legal or at least legal-like) relationship between visitors and non-places, which Augé $(2008,82)$ highlights. Often, one cannot even enter a given non-place without being compelled to follow some rules characteristic to it, not to mention one's subsequent presence and functioning in the non-place, using it in accordance with its main function (e.g. transition, temporary stay, or consumption), while it exerts its influence (detachment, solitude, anonymity, sameness, and deindividualization). This, in connection with Augé's $(2008,82)$ highly legal statement that "[i]n a way, the user of the non-place is always required to prove his [or her - M.D.] innocence," should clearly confirm the specific paradoxical nature of non-places, which is dependent on their legal or legal-like rules.

To experience non-places' ambivalent or, for some, even strictly negative influence on the self, one simply has to keep doing something rather positive, or at least neutral: follow specific rules, just like everyone else should. In nonplaces, in return for "playing fair" or "going by the book" one gets something that not necessarily can be considered fair - detachment, solitude, anonymity, sameness, and deindividualization. These distinctive social, intersubjective traits of non-places are, to a certain yet still significant extent, dependent on non-places' characteristic rules, which sometimes can be controversial and questionable because of their practical interference in individual privacy or even dignity. By contrast, breaking these rules, especially by visitors to non-places, can be said to reverse their default influence. For example, the previously deindividualized is individualized. Naturally, such nonconformity can provoke some legal or legallike reaction with respect to the given nonconformist, a reaction that may be more oppressive than the mere conformity to non-places' legal or legal-like rules. In light of the above discussion, they can definitely be deemed relevant to, and in fact co-responsible for, the intersubjective level of non-places.

\subsection{Non-Places' Subjective Level and the Law}

Augé's presentation of non-places seems to be rather consistent, in the sense that he focuses on detachment, anonymity, deindividualization, and solitude. In consequence, often one could assume that non-places and their experience are negative, that people in them, especially those who do not work there, assess these sites and their feel and functioning unfavorably. However, one must recall that an individual, subjective assessment of a non-place experience does not necessarily have to be coherent with the general undertone of the concept, especially one that can be captured during the first, usually superficial, contact with Augé's views. In the end, categorization and the reduction to a common denominator, so characteristic of non-places, can also be perceived by those who experience them firsthand in a positive way, such as a specific emancipation. To acknowledge this, consider a "stranger in a strange land" scenario. Someone who is not acquainted 
with some of the socio-cultural peculiarities of a given area may feel insecure and act in a very limited way until she or he finds in that area a non-place, a site not influenced by local specificity unknown to him or her, but which is, instead, an example of the realization of globalization processes that multiply the same patterns and solutions in very different contexts. For such a person, even the most typical non-place will not be seen as ambivalent or hostile, but instead as a site of relief and comfort.

The example above is only one of many that can highlight the diverse (from very negative to very positive) individual attitudes toward or assessments of nonplaces. A presentation and discussion of other examples is not necessary here. It is more crucial to stress that even though particular instances of non-places may seem meticulously designed and built at the objective level and realized at the intersubjective level, they still do not incapacitate their visitors' ability to assess them in highly individual, and even seemingly counterintuitive, ways.

One can even venture to make an analogy to Goffmanian total institutions (Goffman 1961). Namely, even prisons, possibly the clearest instance of the latter, are not so utterly totalizing that it is impossible to create in them some degree of familiarity or sense of place, even for those who find themselves in them against their will. Similarly, non-places, despite their dedicated, function-oriented, objective, material traits accompanied by consistently maintained intersubjective, social features and influences characteristic to the sociality developed in them, still cannot set or determine how exactly different people will individually and subjectively approach them. This is simply because people's individual attitudes and assessments, even with respect to the same object or phenomenon, can be and often are varied due to the differences among those people (for instance, cultural, educational, economic, occupational, or even age).

In light of the above, a question remains. How does the law relate to the subjective level of non-places - their diverse, individual assessments made by the different people who use or pass through them? Whereas the law proves to be relevant as co-constitutive at the objective and intersubjective levels, it would be unfounded to argue here that the law also takes part in the ways in which individuals approach non-places. As suggested earlier, their attitudes can have many different bases, such as broadly understood socio-demographic features. However, one can still hypothesize that individuals' legal consciousnesses or attitudes toward the law (e.g. Hertogh 2018) can also explain the ways people approach non-places. For instance, someone from a mature, established liberal democracy and someone from an impoverished country that only recently started to implement democratic institutions more fully might look at the same nonplace and its legal or legal-like peculiarities differently, in accordance with how different their legal consciousnesses may be. Having said that, however, the law - in the sense used in this paper, that is, as institutionally created (mostly by state structures) rules - does not contribute to the subjective level of non-places. 


\section{CONCLUSION}

One can say that the law seems to be generally co-constitutive to non-places, not only in their purely material and physical aspects, as the source of regulations that address their mere construction or maintenance, but also in creating their specific intersubjective, social characteristics by clearly establishing standards of conduct for visitors and staff alike who, through their compliance with these standards, are participating significantly in the production of the distinctive nonplace's atmosphere. However, the law does not seem to take part directly in the creation of individuals' assessments of non-places, which, due to their subjective nature and diverse foundations, can be varied and often counterintuitive at first glance.

Given the different possibilities for interpreting Augé's own account of his concept, the ways in which it has, to date, been understood and even applied for different purposes, the possibility and the need to distinguish and thoroughly characterize various types of non-places, and the different ways of conceptualizing the relationship between spatiality and rules (legal ones included) offered not only by legal geography, the preceding remarks are nothing more than a preliminary proposal for understanding the non-places-law relationship, suggested by Augé himself. In a way, this paper can be read as a specific invitation to begin taking a closer look at this relationship also from completely different perspectives than the very basic one employed above. Only then will we be able to decide which is the most accurate and useful approach.

\section{BIBLIOGRAPHY}

Anders, Gerhard. 2009. "The New Global Legal Order as Local Phenomenon: The Special Court for Sierra Leone." In Spatializing Law: An Anthropological Geography of Law in Society. 137-156. Edited by Franz von Benda-Beckmann, Keebet von Benda-Beckmann and Anne Griffiths. Farnham: Ashgate.

Augé, Marc. 1999. An Anthropology for Contemporaneous Worlds. Translated by Amy Jacobs. Stanford: Stanford University Press.

Augé, Marc. 2008. Non-Places: An Introduction to Supermodernity. Translated by John Howe. Second English-language Edition. London and New York: Verso.

Barr, Olivia. 2016. A Jurisprudence of Movement: Common Law, Walking, Unsettling Place. Abingdon and New York: Routledge.

Blank, Yishai and Issi Rosen-Zvi. 2010. "The Spatial Turn in Legal Theory." HAGAR: Studies in Culture, Polity and Identities 10(1): 37-60.

Bosteels, Bruno. 2003. "Nonplaces: An Anecdoted Topography of Contemporary French Theory." Diacritics 33(3/4): 117-139.

Cohen, Julie E. 2008. "Privacy, Visibility, Transparency, and Exposure.” The University of Chicago Law Review 75(1): 181-201.

Costas, Jana. 2013. "Problematizing Mobility: A Metaphor of Stickiness, Non-Places and the Kinetic Elite.” Organization Studies 34(10): 1467-1485. 
Coyne, Richard and James Stewart. 2007. "Orienting the Future: Design Strategies for Non-Place." In Designing for the 21st Century: Interdisciplinary Questions and Insights. 79-90. Edited by Tom Inns. Aldershot: Gower.

Czaja, Dariusz. 2013. "Nie-miejsca: Przybliżenia, rewizje" ["Non-places: Approximations, Revisions"]. In Inne przestrzenie, inne miejsca: Mapy i terytoria [Other Spaces, Other Places: Maps and Territories]. 79-90. Edited by Dariusz Czaja. Wołowiec: Wydawnictwo Czarne.

Dahlberg, Leif. 2016. Spacing Law and Politics: The Constitution and Representation of the Juridical. Abingdon and New York: Routledge.

Delaney, David. 2010. The Spatial, the Legal and the Pragmatics of World-Making: Nomospheric Investigations. Abingdon: Routledge.

English, Penny. 2003. "Space and Time: The Genius Loci of Ancient Places." Law and Geography: Current Legal Issues Volume 5: 465-482. Edited by Jane Holder and Carolyn Harrison. Oxford: Oxford University Press.

Fitzgerald, Ruth and Linda Robertson. 2006. "Inhabiting the Places and Non-Places of a Residential Home: A Case Study from New Zealand.” Sites: New Series 3(1): 48-71.

Freestone, Robert and Edgar Liu, Eds. 2016. Place and Placelessness Revisited. New York and Abingdon: Routledge.

Gebauer, Mirjam, Helle Thorsøe Nielsen, Jan T. Schlosser and Bent Sørensen, Eds. 2015. NonPlace: Representing Placelessness in Literature, Media and Culture. Aalborg: Aalborg University Press.

Goffman, Erving. 1961. Asylums: Essays on the Social Situation of Mental Patients and Other Inmates. New York: Anchor Books.

Hertogh, Marc. 2018. Nobody's Law: Legal Consciousness and Legal Alienation in Everyday Life. London: Palgrave Macmillan.

Maniscalco, Anthony. 2015. Public Spaces, Marketplaces, and the Constitution: Shopping Malls and the First Amendment. Albany: State University of New York Press.

Merriman, Peter. 2009. "Marc Áuge on Space, Place and Non-Places." The Irish Journal of French Studies 9: 9-29.

Philippopoulos-Mihalopoulos, Andreas. 2015. Spatial Justice: Body, Lawscape, Atmosphere. Abingdon: Routledge.

Ritzer, George. 2007. The Globalization of Nothing 2. Thousand Oaks: Pine Forge Press.

Tawil-Souri, Helga. 2011. "Qalandia Checkpoint as Space and Nonplace." Space and Culture 14(1): 4-26.

Whitecross, Richard W. 2009. "Migrants, Settlers and Refugees: Law and the Contestation of 'Citizenship' in Bhutan." In Spatializing Law: An Anthropological Geography of Law in Society. 57-74. Edited by Franz von Benda-Beckmann, Keebet von Benda-Beckmann and Anne Griffiths. Farnham: Ashgate.

Young, Alison. 2014. Street Art, Public City: Law, Crime and the Urban Imagination. Abingdon and New York: Routledge. 